S. Afr. J. Agric. Ext.

Vol. 47 No. 1, 2019: 103 - 117

http://dx.doi.org/10.17159/2413-3221/2019/v47n1a493
Chimonyo, Mutengwa,

Chiduza \& Tandzi

(License: CC BY 4.0)

\title{
PARTICIPATORY VARIETY SELECTION OF MAIZE GENOTYPES IN THE EASTERN CAPE PROVINCE OF SOUTH AFRICA
}

\author{
Chimonyo, V. G. P. ${ }^{1}$, Mutengwa, C. S $^{1}$, Chiduza, C. ${ }^{1}$ and Tandzi, L.N. ${ }^{1}$ \\ Correspondence Author: C.S. Mutengwa. Email address: cmutengwa@ufh.ac.za
}

\begin{abstract}
Participatory variety selection (PVS) is important in understanding farmers' selection criteria, raising awareness, and facilitating adoption of improved varieties. This study aimed to understand farmers' maize selection criteria, identify superior varieties based on farmers' selections, combined with use of agronomic yield data. The study was conducted in Jixini and Mkhwezo in the Eastern Cape Province of South Africa. Focus group discussions (FGD) and semi-structured questionnaires were used to identify maize selection criteria. Seven maize open pollinated varieties (OPVs) from CIMMYT-Zimbabwe (ZM 305, ZM 423 ZM 501, ZM 525, Obatanpa, ZM 621, ZM 627), two from IITA-Nigeria (BR 993, and Comp 4), three locally grown maize OPVs (Okavango, Afric 1 and Nelson's Choice) and a hybrid check (Pan 6479) were evaluated together with farmers in each of the villages. Farmer-selection criteria common to both villages were ear traits such as taste, long cobs, and big kernels. Other traits, such as prolificacy, early maturity, retainability of seed and dark leaves were village specific. Three varieties (Okavango, ZM 305 and ZM 501) were selected by farmers. In addition, there were no significant differences between the highest yielding varieties within each site. Farmers' choices were, therefore, consistent with selections made based on yield performance. However, some of the important traits for farmers, such as taste, were not normally prioritised, but should be considered when developing or recommending varieties. This will increase the likelihood of their adoption in marginal areas of South Africa.
\end{abstract}

Keywords: Participatory variety selection, selection criteria, farmer, maize

\section{INTRODUCTION}

Maize (Zea mays L.) is the most important cereal crop in South Africa, and it is produced throughout the country under diverse environments. In the Eastern Cape Province (EC), it is mainly produced by resource-poor farmers in low-input environments. A survey of 33 projects conducted in 2005 prior to introduction of the Siyakhula/ Massive maize project revealed that $69.72 \%$ of the maize yields were below one tonne per hectare, and a further $18.18 \%$ of the yields were between 1-2 t/ha (Tregurtha, 2009). Under irrigation, Fanadzo (2007) reported average yields of $1.8 \mathrm{t} / \mathrm{ha}$ while the Massive Food Production Program (MFPP) observed yields of up to 3.7 t/ha in 2007/2008 cropping season (Tregurtha, 2009). To date, EC imports large amounts of maize from other provinces on an annual basis (Tregurtha, 2009), which can partly be attributed to the low maize yields being obtained in the province. Reasons for low productivity have been reported to include socio-economic (Monde, 2003), biophysical (van Averbeke \& Bennett, 2007) and agronomic (Fanadzo et al., 2010) factors. Among agronomic factors, it has been suggested that varieties currently in use may not be entirely adapted to the EC (Fanadzo et al., 2010; Matiwana, 2011). This may be a result of limited farmerparticipatory evaluation of candidate varieties in the diverse agro-ecologies of the EC.

\footnotetext{
${ }^{1}$ Department of Agronomy, Faculty of Science and Agriculture, University of Fort Hare, P. Bag X1314, Alice, 5700, SA. cmutengwa@ufh.ac.za / Tel. (27) 727062495
} 
S. Afr. J. Agric. Ext.

Vol. 47 No. 1, 2019: 103 - 117

http://dx.doi.org/10.17159/2413-3221/2019/v47n1a493
Chimonyo, Mutengwa,

Chiduza \& Tandzi

(License: CC BY 4.0)

Farmers' limited knowledge of new varieties (Hebinck, Fay \& Kondlo, 2011; Jacobson \& Myhr, 2013) might also be contributing to the generally low yields and poor adoption of improved varieties in the EC. Within the EC, the majority $(75 \%)$ of smallholder farmers were found to use traditional maize varieties (Silwana, 2000). Such varieties would either be grown alone or in conjunction with certified hybrid or open pollinated varieties (OPVs) and retained hybrid or OPV seed. Chimonyo (2012) reported that the predominant varieties used in some villages of the EC were local landraces (53\%), followed by hybrids (31\%) and improved OPVs $(11 \%)$. While these statistics might suggest an increased use of improved varieties over the years in the EC, there is still a need for raising awareness, and promoting use of improved varieties. Miti (2007) reported that food security was negatively correlated with the use of landrace maize varieties and low yields of maize in Zambia. Landraces are known to be of good adaptation to local environment and they tend to be low yielding in comparison to improved varieties (Tandzi et al., 2015). It is widely believed that using improved and adapted maize varieties could significantly increase productivity, food security and overall household income (Ngonkeu et al., 2017; Tandzi et al., 2015). As a way of improving maize production in the EC, there is a need to increase access and availability of improved maize varieties.

As a response to several challenges faced by resource-poor farmers located in marginal areas, the International Maize and Wheat Improvement Centre (CIMMYT) and International Institute of Tropical Agriculture (IITA) continually develop a range of stress tolerant maize OPVs (Setimela et al., 2007). Vigorous stress screening programmes resulted in the production of numerous maize OPVs that are not only tolerant to diverse biotic and abiotic stresses but are also high yielding. Such varieties (e.g. ZM 621, ZM 305, ZM 521 and Obatanpa) have been developed and released in numerous African countries (Bänziger et al, 2005; Gadzirirayi et al., 2006; Magorokosho, Vivek \& Macrobert, 2008; Mphalala, 2007). Sibanda, Mushunje and Mutengwa (2016) found that it would be profitable for resource-poor smallholder farmers to grow improved OPVs' in the EC given that the province is semi-arid and taking into account the high management cost associated with chemical inputs required to realise hybrid yield potential. Therefore, introduction of the low cost, highly adaptable and stress tolerant OPVs (Chimonyo, Mutengwa \& Chiduza, 2014) could help farmers in the EC's former homelands to increase maize productivity. This could also have a significant contribution towards improved rural livelihoods and alleviation of poverty. However, according to Joshi and Witcombe (1996), the farmers willingness to adopt new varieties is often met with resistance.

Participatory variety selection (PVS) was initiated to facilitate identification of farmers' ideal plant varieties, as well as enhancing adoption of elite varieties. This approach aims to increase the efficiency of the final stage of the plant breeding process, consisting of selection among released, or nearly released, varieties (Abebe et al, 2005; Bucheyeki et al., 2011). During PVS, information is gathered on farmers' variety preferences, which helps in narrowing down the possible varieties to be introduced in a community. It is important to understand farmers' perceptions of any technology as this influences its level of adoption. Participatory variety selection (PVS) requires formation of strong partnerships between farmers, researchers and development workers to ensure wider technology promotion and adoption (Abebe et al., 2005; Bucheyeki et al., 2011). Developing varieties based on farmers' selection criteria was reported to enhance their productivity and dissemination among farmers (Rahman et al., 2015). When implemented under selected stress conditions, this approach enables researchers to better understand the trade-offs that farmers make between various qualitative and quantitative traits in a relevant environment (Bänziger et al., 2000). Successful variety introduction and adoption using PVS has been reported in many countries, such as rice in Nepal (Joshi \& Witcombe, 
1996), maize in Ethiopia (Abebe et al., 2005; Tadesse, Medhin \& Ayalew, 2014) and sorghum in Malawi (Nkongolo et al., 2008). Increasing the adoption rate of improved maize varieties at farmer level necessitates identification of farmer-preferred traits. Therefore, the objectives of this study were twofold: 1) to understand farmers' maize selection criteria, and 2) to identify superior varieties based on farmers' selections, combined with the use of agronomic yield data in selected villages of the EC. Understanding farmers' maize selection criteria provides important information which improves focus when developing varieties that meet farmers' preferences in target agro-ecologies, and also increases chances of acceptance and adoption.

\section{MATERIALS AND METHODS}

\subsection{District selection and characterisation}

The study was conducted during the 2009/10 and 2010/11 summer seasons in the O. R. Tambo District Municipality (ORTDM) $\left(33^{\circ} 34^{\prime} \mathrm{S} 28^{\circ} 46^{\prime} \mathrm{E}\right)$ of the EC, South Africa, where IsiXhosa is the language spoken by the dominant ethnic group. The district was selected due to its geographic, historic and diverse ecological characteristics. O. R. Tambo district municipality has an estimated population of 1.46 million. According to McCain (2005), 82.2\% of these people live below the world poverty datum line. Comparing with the other districts in the EC, ORTDM has the largest proportion $(90.8 \%)$ of inhabitants that live in rural areas. Subsistence agriculture is predominant, with small scale farming and open grazed livestock (Musemwa et al., 2008). Due to variations in rainfall distribution $(600$ to $1800 \mathrm{~mm})$, altitude $(0-1650$ meters above sea level (masl)), and soil characteristics, agricultural potential across the district differs immensely (Agricultural Geo-Referenced Information System (AGIS), 2011).

Jixini and Mkhwezo villages were selected to participate in the study based on contrasting agroecologies, as well as through consultation with ward extension officers. Located in a moderately high rainfall area with an annual precipitation ranging from 800 to $1000 \mathrm{~mm}$, Jixini ( $31^{\circ} 43^{\prime} \mathrm{S} 28^{\circ} 50^{\prime} \mathrm{E}$ ) has an average altitude of 643 masl (AGIS, 2011). Based on agro-ecological classification, Jixini is said to have a sub-tropical to semi-arid climate with clay loam black soils. The rural population (750 inhabitants) is sparsely distributed and covers approximately $5 \mathrm{~km}^{2}$ (Water Service Report Tool, 2011). The second village, Mkhwezo (31 ${ }^{\circ} 42^{\prime} \mathrm{S} 28^{\circ} 30^{\prime} \mathrm{E}$ ), is located in a lower rainfall area, with annual precipitation of between 600 and $800 \mathrm{~mm}$. The average altitude of this village is 942 masl (AGIS, 2011) and it has an arid to semi-arid climate with light brown sandy loam soils. The rural population (1250 inhabitants) is also sparsely distributed, covering approximately $8 \mathrm{~km}^{2}$ (Water Service Report Tool, 2011). Winter rain contributes approximately $20 \%$ to the total annual precipitation of ORTDM (Bothma, 2004).

Based on willingness to participate in the study, and through further consultation with ward extension officers, a single farmer was identified to host a yield trial in each village. Farmers were then invited later to participate in selecting from the 13 varieties that were in these trials.

\subsection{Treatments and experimental design}

The trial evaluated 13 varieties, seven OPVs from CIMMYT, two OPVs from IITA, and four local checks as shown in Table 1 . The experiment was laid out in a randomised complete block design (RCBD), replicated three times at each site. 
S. Afr. J. Agric. Ext.

Vol. 47 No. 1, 2019: 103 - 117

http://dx.doi.org/10.17159/2413-3221/2019/v47n1a493
Chimonyo, Mutengwa,

Chiduza \& Tandzi

(License: CC BY 4.0)

Table 1: Characteristics of maize varieties included in the participatory yield trials conducted in Jixini and Mkhwezo

\begin{tabular}{|c|c|c|c|c|c|c|}
\hline Code & Variety & Origin & $\begin{array}{l}\text { Seed } \\
\text { colour }\end{array}$ & Type & Maturity $^{1}$ & $\begin{array}{l}\text { Yield } \\
\text { potential } \\
\text { (t/ha) }\end{array}$ \\
\hline 1 & ZM 305 & CIMMYT-Zim & White & OPV & $\mathrm{E}$ & $2-4$ \\
\hline 2 & $\mathrm{ZM} 423$ & CIMMYT-Zim & White & OPV & $\mathrm{E}$ & $2-6$ \\
\hline 3 & ZM 501 & CIMMYT-Zim & White & OPV & $E-M$ & $2-6$ \\
\hline 4 & ZM 525 & CIMMYT-Zim & White & OPV & $E-M$ & $2-6$ \\
\hline 5 & ZM 621 & CIMMYT-Zim & White & OPV & $\mathrm{M}$ & $3-6$ \\
\hline 6 & ZM 627 & $\begin{array}{l}\text { CIMMYT- } \\
\text { Zim }^{3}\end{array}$ & White & OPV & M & $2-5$ \\
\hline 7 & BR993 & IITA-Ghana & White & OPV & $\mathrm{L}$ & $2-5$ \\
\hline 8 & COMP 4 & IITA-Ghana & White & OPV & $\mathrm{L}$ & $2-5$ \\
\hline 9 & Obatanpa & CIMMYT-Zim & White & OPV & $M-L$ & $2-5$ \\
\hline 10 & AFRIC $1^{2}$ & $\begin{array}{l}\text { Nelson's } \\
\text { Genetics-SA }\end{array}$ & White & OPV & M & $1.5-6$ \\
\hline 11 & Okavango $^{2}$ & Capstone-SA & White & OPV & $\mathrm{L}$ & $4-5$ \\
\hline 12 & $\begin{array}{l}\text { Nelson's } \\
\text { Choice }^{2}\end{array}$ & $\begin{array}{l}\text { Nelson's } \\
\text { genetics-SA }\end{array}$ & Yellow & OPV & $M-L$ & $4-5$ \\
\hline 13 & Pan $6479^{2}$ & PANNAR & White & HYBRID & $\mathrm{M}$ & $5-10$ \\
\hline
\end{tabular}

${ }^{1}$ Maturity class in terms of days to 50\% flowering in low altitudes: Early (E) 60-65; Medium (M) 65-70; Long (L) 70-75 (Magorokosho et al., 2008)

${ }^{2}$ Check varieties

${ }^{3} \mathrm{Zim}-$ Zimbabwe

${ }^{4} \mathrm{SA}$ - South Africa

There were different randomisation of treatments at each site. Gross plot size was $5 \mathrm{~m}$ by 4.5 $\mathrm{m}$ with a total of five, $5 \mathrm{~m}$ long rows. The net plots consisted of the three middle rows. The two outside rows were considered as discards or border rows. Plant spacing was $0.9 \mathrm{~m}$ between rows and $0.3 \mathrm{~m}$ within the row for a target population of 37000 plants/ha.

\subsection{Non-experimental variables}

Land preparation involved an initial deep ploughing, followed by disking using tractor drawn implements to obtain a fine tilth. Planting holes were opened using hoes and three seeds were planted. The plants were later thinned to one per planting station two weeks after emergence. A basal fertilizer (N: P: K ratio of 2:3:4 (30)) was applied at a rate of $185 \mathrm{~kg} / \mathrm{ha}$ at planting to give a nutrient ratio $(\mathrm{kg})$ of $12.4 \mathrm{~N}: 18.5 \mathrm{P}: 24.6 \mathrm{~K}$. Lime ammonium nitrate (LAN) $(28 \% \mathrm{~N})$ was applied at a rate of $185 \mathrm{~kg} / \mathrm{ha} 6$ weeks after crop emergence with $\mathrm{N}$ fertilizer application at $64 \mathrm{~kg} / \mathrm{ha}$. Weeds were controlled for using pre-planting and post-emergence herbicides, while insects were controlled using insecticides (Chimonyo et al., 2014). Plants from net plots were harvested at maturity and cobs were hand shelled. A Protimeter Grain Moisture meter $\left(\right.$ Grainmaster $\left.^{\circledR}\right)$ was used to standardise grain yield per plot at $12.5 \%$ moisture content. 
S. Afr. J. Agric. Ext.

Vol. 47 No. 1, 2019: 103 - 117

http://dx.doi.org/10.17159/2413-3221/2019/v47n1a493
Chimonyo, Mutengwa,

Chiduza \& Tandzi

(License: CC BY 4.0)

\subsection{Data collection}

At physiological maturity, farmers from Jixini and Mkhwezo villages were invited to attend a field day. Maize cobs from the outer rows of each plot were de-husked to allow farmers to assess varieties based on cob and other plant parameters. Farmers in each village were placed into five groups of three people each and were asked to select the three most preferred varieties. Thereafter, they were asked to provide reasons for their choices. The traits that were mentioned were considered as field-based selection criteria. Data on variety selections from each group were consolidated to come up with the top five varieties for each village. At harvest maturity (when grains were fairly dry, such that they would not deteriorate in quality when harvested), net plots were harvested and shelled to obtain grain weight which was then used to calculate grain yield in t/ha. After determining moisture content, grain yield was adjusted to $12.5 \%$ using the following formula: Grain yield $=[(100$-moisture content $) / 87.5] *$ yield $/$ ha.

\subsection{Farmer surveys}

To identify selection criteria used by farmers when selecting maize varieties, both informal (focus group discussions (FGDs)) and formal (involving distribution of structured questionnaires) surveys were used during the 2009/10 and 2010/11 seasons, respectively. During the discussions, a checklist with all visible maize traits was used for guidance in identifying farmer selection criteria. Based on results of the informal survey, a semi-structured questionnaire was then designed with the intention of validating information on specific issues and testing hypotheses devised by researchers after FGDs. Formal surveys were conducted in the same areas where FGDs were held, and this involved interviews with 70 individual maize growing farmers.

\subsection{Statistical analyses}

Statistical analysis of grain yield data was performed using GenStat Statistical Software, version 4.2. A Bartlett's test (Gomez \& Gomez, 1984) was performed to determine homogeneity of error variances before combining data of the two sites. This test showed homogeneity of error variances for both sites, allowing combined analysis to be done for grain yield. Duncan's multiple range test was used to separate significantly different means at $\mathrm{p}<0.05$. Data collected from FGDs and questionnaires were coded and also subjected to analysis of variance using the Statistical Package for Social Sciences $\left(\right.$ SPSS $^{\circledR}$ ) version 15 (SPSS Inc., Chicago IL).

\section{RESULTS}

\subsection{Participatory evaluation of stress tolerant maize open pollinated varieties}

Farmers' variety preferences and ranking varied between the villages as shown in Table 2 . Three varieties were selected in both villages, namely Okavango, ZM 305, and ZM 501. Other varieties also selected included Nelson's Choice, Afric 1, ZM 621, and ZM 423. In Mkhwezo, the variety ZM 305 was ranked first, while in Jixini village, Okavango received the top ranking. 
S. Afr. J. Agric. Ext.

Vol. 47 No. 1, 2019: 103 - 117

http://dx.doi.org/10.17159/2413-3221/2019/v47n1a493
Chimonyo, Mutengwa,

Chiduza \& Tandzi

(License: CC BY 4.0)

Table 2: Rank positions of varieties selected by farmers in Mkhwezo and Jixini

\begin{tabular}{|c|c|c|c|c|c|}
\hline \multirow{2}{*}{ Village } & \multicolumn{5}{|l|}{ Rank } \\
\hline & 1 & 2 & 3 & 4 & 5 \\
\hline Jixini & Okavango & ZM 621 & ZM 501 & ZM 305 & ZM 423 \\
\hline Mkhwezo & ZM 305 & Nelson's choice & Okavango & ZM 501 & Afric 1 \\
\hline
\end{tabular}

Traits desired by farmers, from the most to the least preferred, were short to medium plant height, long cobs, a large number of kernel rows ( $\geq 12)$, prolificacy, good cob filling, big kernel size, flint kernels, and early maturity. However, farmers also pointed out some weaknesses in the varieties they selected (Table 3 ).

Table 3: Presence or absence of preferred traits in varieties selected by farmers across the study sites

\begin{tabular}{|c|c|c|c|c|c|c|c|c|c|c|}
\hline \multirow[b]{3}{*}{ Traits preferred } & \multicolumn{10}{|c|}{ Varieties selected } \\
\hline & \multicolumn{5}{|c|}{ Jixini } & \multicolumn{5}{|c|}{ Mkhwezo } \\
\hline & $\begin{array}{l}\mathrm{ZM} \\
423\end{array}$ & $\begin{array}{l}\mathrm{ZM} \\
621\end{array}$ & $\begin{array}{l}\mathrm{ZM} \\
305\end{array}$ & $\begin{array}{l}\mathrm{ZM} \\
501\end{array}$ & OKA & $\begin{array}{l}\mathrm{ZM} \\
305\end{array}$ & $\begin{array}{l}\mathrm{ZM} \\
501\end{array}$ & OKA & $\begin{array}{l}\text { AFRI } \\
\text { C1 }\end{array}$ & $\mathrm{NC}$ \\
\hline $\begin{array}{l}\text { Short to medium } \\
\text { plant height }\end{array}$ & $\sqrt{ }$ & - & $\sqrt{ }$ & $\sqrt{ }$ & $\sqrt{ }$ & $\sqrt{ }$ & $\sqrt{ }$ & - & $\sqrt{ }$ & $\sqrt{ }$ \\
\hline Long cob & $\sqrt{ }$ & $\sqrt{ }$ & $\sqrt{ }$ & - & $\sqrt{ }$ & $\sqrt{ }$ & $\sqrt{ }$ & $\sqrt{ }$ & - & $\sqrt{ }$ \\
\hline $\begin{array}{l}\text { Kernel rows } \\
(\geq 12)\end{array}$ & $\sqrt{ }$ & $\sqrt{ }$ & $\sqrt{ }$ & $\sqrt{ }$ & $\mathrm{x}$ & $\sqrt{ }$ & $\sqrt{ }$ & $\mathrm{x}$ & - & $\sqrt{ }$ \\
\hline Prolific & $\sqrt{ }$ & $\sqrt{ }$ & $\sqrt{ }$ & $\sqrt{ }$ & - & $\sqrt{ }$ & - & - & - & \\
\hline Good cob filling & $\sqrt{ }$ & $\sqrt{ }$ & $\sqrt{ }$ & - & $\mathrm{x}$ & $\sqrt{ }$ & - & $\mathrm{x}$ & $\sqrt{ }$ & \\
\hline Big kernel size & $\sqrt{ }$ & $\sqrt{ }$ & $\sqrt{ }$ & - & - & $\sqrt{ }$ & $\sqrt{ }$ & - & $\sqrt{ }$ & - \\
\hline $\begin{array}{l}\text { Kernel shape } \\
\text { (flint) }\end{array}$ & $\sqrt{ }$ & $\sqrt{ }$ & $\sqrt{ }$ & - & - & $\sqrt{ }$ & - & $\sqrt{ }$ & - & $\sqrt{ }$ \\
\hline Early maturity & $\sqrt{ }$ & - & $\sqrt{ }$ & - & - & $\sqrt{ }$ & $\sqrt{ }$ & - & - & - \\
\hline Good husk cover & - & - & $\sqrt{ }$ & - & $\mathrm{x}$ & - & - & $\mathrm{x}$ & $\sqrt{ }$ & - \\
\hline Thick stem & $\sqrt{ }$ & - & - & $\sqrt{ }$ & - & - & $\sqrt{ }$ & - & - & - \\
\hline Kernel colour & $\mathrm{X}$ & $\mathrm{x}$ & - & - & $\sqrt{ }$ & $\mathrm{x}$ & - & $\sqrt{ }$ & $\mathrm{x}$ & - \\
\hline
\end{tabular}

$\sqrt{ }$ Indicates desirable traits that a variety was identified to have

- Indicates that the trait was not mentioned for corresponding variety

$\mathrm{x}$ Indicates a desirable trait that a variety was identified to be lacking

In the case of kernel colour, + refers to yellow kernels would be more preferred

Though Okavango was preferred mainly because of its yellow grain colour, farmers from both villages reported that it had few kernel rows, poor cob filling and poor husk covering (Table 3). Farmers also indicated that ZM 305, ZM 423, ZM 621 and Afric 1 would have been more desirable if the kernels were yellow.

\subsection{Agronomic evaluation of stress tolerant varieties}

There was a significant $(\mathrm{p}<0.001)$ interaction between variety and site (Table 4). Overall mean grain yield was higher (5.50 t/ha) in Jixini than in Mkhwezo (3.02 t/ha). In Jixini, Pan 6479 was the highest yielding variety (6.68 t/ha) and showed no significant difference with ZM 525, which had a yield of $6.48 \mathrm{t} / \mathrm{ha}$. 
S. Afr. J. Agric. Ext.

Vol. 47 No. 1, 2019: 103 - 117

http://dx.doi.org/10.17159/2413-3221/2019/v47n1a493
Chimonyo, Mutengwa,

Chiduza \& Tandzi

(License: CC BY 4.0)

Table 4: Performance of varieties and ranking according to grain yield ( $\mathrm{t} / \mathrm{ha}$ ) in Jixini and Mkhwezo

\begin{tabular}{|c|c|c|c|c|}
\hline \multirow[t]{2}{*}{ Variety } & \multicolumn{4}{|l|}{ Site } \\
\hline & Jixini & Rank & Mkhwezo & Rank \\
\hline PAN & $6.68 \mathrm{a}$ & 1 & $2.65 \mathrm{cde}$ & 11 \\
\hline ZM 525 & $6.48 \mathrm{ab}$ & 2 & $3.31 \mathrm{~b}$ & 5 \\
\hline AFRIC 1 & $6.07 \mathrm{abc}$ & 3 & $3.33 \mathrm{~b}$ & 4 \\
\hline OKA & $6.14 \mathrm{abcd}$ & 4 & $2.72 \mathrm{cde}$ & 10 \\
\hline ZM 423 & $5.71 \mathrm{abcd}$ & 5 & $2.88 \mathrm{c}$ & 8 \\
\hline ZM 621 & $5.60 \mathrm{bcd}$ & 6 & $2.52 \mathrm{de}$ & 12 \\
\hline $\mathrm{ZM} 627$ & $5.65 \mathrm{bcd}$ & 7 & $2.47 \mathrm{e}$ & 13 \\
\hline ZM 501 & $5.33 \mathrm{def}$ & 8 & $2.98 \mathrm{c}$ & 7 \\
\hline ZM 305 & $5.03 \mathrm{cdef}^{1}$ & 9 & $3.49 \mathrm{ab}$ & 2 \\
\hline $\mathrm{NC}$ & $5.01 \mathrm{cdef}$ & 10 & $3.24 \mathrm{~b}$ & 6 \\
\hline COMP 4 & $4.77 \mathrm{def}$ & 11 & $2.78 \mathrm{~cd}$ & 9 \\
\hline OBA & $4.69 \mathrm{ef}$ & 12 & $3.79 \mathrm{~b}$ & 1 \\
\hline BR 993 & $4.26 \mathrm{f}$ & 13 & $3.34 \mathrm{~b}$ & 3 \\
\hline Mean & 5.50 & & 3.02 & \\
\hline $\mathbf{P}_{0.05}$ & $* * *$ & & NS & \\
\hline DMRT & 0.99 & & 0.30 & \\
\hline $\mathbf{C V}$ & 10.69 & & 18.04 & \\
\hline
\end{tabular}

OBA - Obatanpa; NC - Nelson's Choice; OKA - Okavango; PAN - Pan 6479;

${ }^{1}$ Means followed by similar letters are not significantly different at $\mathrm{p}<0.001$ based on DMRT test

NS - Not significant

Interaction between site and variety was also significant at $\mathrm{p}<0.001$

$\mathrm{CV}=14.8$

$\operatorname{DMRT}_{(0.05)}=0.98$

The lowest yielding varieties in Jixini were Comp 4 (4.77 t/ha), Obatanpa (4.69 t/ha) and BR $993(4.26 \mathrm{t} / \mathrm{ha})$, and they were ranked $11^{\text {th }}, 12^{\text {th }}$ and $13^{\text {th }}$ respectively. Yields of these varieties were also not significantly different from each other. Obatanpa (3.79t/ha) was ranked first in Mkhwezo, and it was followed by ZM 305 (3.49 t/ha) and BR 993 (3.34 t/ha), which ranked second and third respectively (Table 4). The low yielding varieties in this site were Pan 6479 $(2.65 \mathrm{t} / \mathrm{ha}), \mathrm{ZM} 621(2.52 \mathrm{t} / \mathrm{ha})$ and $\mathrm{ZM} 627(2.47 \mathrm{t} / \mathrm{ha})$, which ranked $11^{\text {th }}, 12^{\text {th }}$ and $13^{\text {th }}$ respectively. Interaction between varieties and site was a result of changes in rankings of varieties between sites.

\subsection{Farmers' selection criteria}

Selection criteria used by farmers in both villages and importance of the criteria were different (Table 5). There was a highly significant difference $(\mathrm{p}<0.01)$ between the villages for farmers selecting varieties according to their ability to be retained. More farmers in Jixini $(26.5 \%)$ selected varieties based on their ability to be retained as compared to 5.6\% in Mkhwezo. A higher percentage of farmers in Jixini (11.8\%) selected varieties based on their adaptability to 
S. Afr. J. Agric. Ext.

Vol. 47 No. 1, 2019: 103 - 117

http://dx.doi.org/10.17159/2413-3221/2019/v47n1a493
Chimonyo, Mutengwa,

Chiduza \& Tandzi

(License: CC BY 4.0)

the local environment as compared to Mkhwezo (8.33\%). Farmers in Mkhwezo (15.62\%) used prolificacy as selection criterion while farmers in Jixini did not (Table 5).

Table 5: Farmers' ranking of traits used in selecting varieties

\begin{tabular}{|c|c|c|c|}
\hline Source & Jixini & Mkhwezo & Mean \\
\hline Retainable seed & $26.5(1)$ & 5.6 & $16.05(4)^{* *}$ \\
\hline Big leaves & $23.4(2)^{1}$ & 11.1 & $17.25(3)$ \\
\hline Brace roots & $20.6(3)$ & 2.7 & 11.65 \\
\hline Taste & $17.6(4)$ & $55.5(1)$ & $36.55(1)$ \\
\hline Big kernels & $14.7(5)$ & $16.7(4)$ & $15.7(5)$ \\
\hline Long cob & $14.7(5)$ & $52.8(2)$ & $33.75(2)$ \\
\hline Matures early & $14.7(5)$ & 8.33 & 11.50 \\
\hline Thick stems & $14.7(5)$ & 2.82 & 8.76 \\
\hline Dark green leaves & 5.8 & $25.0(3)$ & 15.40 \\
\hline Drought tolerance & 5.8 & $13.9(5)$ & 9.85 \\
\hline Medium kernels & 0 & 5.5 & 2.75 \\
\hline Upright leaves & 8.8 & 5.5 & 7.15 \\
\hline Yellow maize & 0 & 11.1 & 5.65 \\
\hline Soft kernels & 2.9 & 0 & 1.45 \\
\hline Lodging resistance & 13.8 & 0 & 2.9 \\
\hline Tolerance to heavy rains & 2.94 & 0 & 1.47 \\
\hline High yield & 8.82 & 8.33 & 8.56 \\
\hline Many kernel rows & 0 & 8.33 & 4.17 \\
\hline Resistant to cob rots & 2.9 & 5.62 & 4.26 \\
\hline Good husk cover & 5.8 & 2.83 & 4.32 \\
\hline $\begin{array}{l}\text { Adaptable } \\
\text { environment }\end{array}$ to $\quad$ our & 11.8 & 8.33 & 10.07 \\
\hline Prolific & 0 & 15.62 & $7.81 *$ \\
\hline
\end{tabular}

${ }^{1}$ Number in parenthesis represents overall rank position

*, ** - Significant difference between village at $\mathrm{p}<0.01$ and $\mathrm{p}<0.05$ respectively

Bartlett's $X^{2}=20.0$, Degrees of Freedom $(n-1)=14$

$\mathrm{P}=0.130 \mathrm{~ns}$ 
In Jixini, the top four important traits used in variety selection, in order of their importance, were retainable seed (26.5\%), big leaf size (23.4\%), presence of brace roots $(20.6 \%)$, and taste (17.6\%). The fifth place was shared by big cobs (14.7\%), big kernels $(14.7 \%)$, early maturity (14.7\%), and thick stems (14.7\%) (Table 5). In Mkhwezo, the top five traits mentioned were taste $(55.5 \%)$, long cobs $(52.8 \%)$, dark green leaf colour $(25.0 \%)$, big kernels $(16.7 \%)$, and drought tolerance $(13.9 \%)$. The overall importance of a selection criterion was computed based on the accumulative frequency of farmers mentioning it as being important across the two villages. Overall, the selection criteria, in order of their importance, were taste (36.55\%), long cobs $(33.75 \%)$, big leaves (17.25\%), retainable seed (16.05\%), and big kernels $(15.7 \%)$.

\section{DISCUSSION}

The PVS methodology allowed farmers to objectively select preferred varieties from a range of local and newly introduced stress tolerant maize varieties. Selection of varieties by farmers in each village was observed to be different, however, it was consistent with high performance based on yield data of the varieties for each village. It can therefore be deduced that environmental effects on varietal performance could have caused some varieties to be more desirable to farmers in one village than the other, and vice versa. These results agree with Courtois et al. (2001), and suggest the presence of genotype and environment interaction effects on variety performance.

The observed field-based criteria used in the selection of varieties during PVS were somewhat similar for both villages, the majority being ear and kernel characteristics. This could be because farmers have a tendency of rating varieties based on particular and desired traits that they want to see in their fields. It is notable that selection of varieties by farmers for future planting is largely based on ear and grain characteristics (Louette \& Smale, 2000). The study also highlighted the importance of grain colour as a selection criterion, though it was not in the top five in the villages that were investigated. Firstly, farmers indicated that varieties ZM 305, ZM 423, ZM 621 and Afric 1 would have been more desirable if they were yellow. Secondly, variety Okavango was chosen due to its yellow grain colour and ranked high despite having the highest number of undesirable traits, such as a low kernel row number, poor grain filling, and poor husk covering. In Jixini, it was ranked first, while in Mkhwezo it was ranked third. This would suggest that farmers in Jixini were not willing to trade-off yellow grain colour even though the variety possessed undesirable traits. Farmers in Mkhwezo were able to forgo Okavango for those that had more favourable traits, such as ZM 305, which they ranked first. However, Okavango's selection and yield performance in both villages could also be an indication of its wide adaptation. The findings also suggested that differences in farmerpreferred characteristics and perceptions could have had a bearing on variety selection in the two villages. This gives the relevance of involving farmers in the selection process of the improved maize genotypes. According to Singh et al. (2013), plant breeders develop improved varieties isolated from the active farmers and release them without checking if they are suitable or not for marginal farm conditions.

The observation that white varieties selected by farmers would have been more desirable if they were yellow could affect potential adoption of these new white-seeded varieties. Although white maize is preferred for food consumption, yellow maize sells better because it is sold in bulk to commercial farmers (for stock feed) and to surrounding communities (Masifunde Education and Development Trust Programme (MEDTP), 2010). In South Africa, yellow maize is primarily used for animal feed manufacturing whereas white kernel maize is used for 
human consumption (Department of Agriculture, Forestry and Fisheries (DAFF), 2012). There is a dominance of livestock farming in the EC. It has been reported in 2016 that the EC $(77.6 \%)$ and Free State $(72.4 \%)$ were the leading agricultural households that farmed more than 100 head of cattle in South Africa with an estimation of $67 \%$ of animal combination farming (livestock and poultry) in the EC (Stats SA, 2016). Farmers believe that yellow maize has a higher nutrient content than white maize (De Groote et al, 2004). According to Mapiye et al. (2009), most grazing fields in the province are eroded and poor in quality. Farmers, therefore, use yellow maize as a supplementary feed for their animals. The introduction of quality protein maize (QPM) varieties, such as Obatanpa, could also play an important role in supplying quality nutrition for livestock. For human beings, it has been proven that consuming opaque-2 in QPM varieties improves the growth rates and nitrogen metabolism, making it as efficacious as consuming milk casein (Nuss \& Tanumihardjo, 2011). Based on yield, variety Obatampa was ranked first in Mkhwezo while it was $12^{\text {th }}$ in Jixini (Table 4). The rank-switching of this OPV might suggest instability of performance across sites. However, twenty QPM cultivars are available in South Africa (DAFF, 2015), and could be considered for cultivation and livestock feeding in the EC.

The observed selection criteria had a combination of yield components (rows per ear, kernel size, number of kernels, prolificacy, and cob length) and adaptive traits (earliness to maturity and plant height). This was chiefly in response to prevailing agro-ecological conditions, which seem to have resulted in selection criteria being site specific. The high ranking of dark green leaves observed in Mkhwezo could be explained by the poor inherent soil fertility status of most sandy loam soils as compared to the clay soils found in Jixini, where such a trait was not mentioned at all. Furthermore, sandy loam soils are prone to leaching of nutrients when there is too much rain. The heavy rains experienced during the 2010/2011 season suggest that a lot of nutrients could have been leached from the soil, resulting in pale green leaves in farmers' fields. Therefore, farmers desire to have varieties with dark green leaves equated to having varieties that are tolerant to low soil fertility. The new introductions from CIMMYT and IITA were specifically screened for tolerance to low soil $\mathrm{N}$ (Magorokosho et al., 2008). The screening methodology used by CIMMYT involves evaluating the germplasm under controlled abiotic stress conditions as well as under high-input unstressed conditions (Araus, Serret \& Edmeades 2012; Bänziger \& Cooper 2001), so that good yields can be obtained during years in which conditions will be more favourable. This would suggest that their use can increase maize productivity in Mkhwezo. In addition to adopting such varieties, however, farmers would still need to use good soil management practices to improve soil fertility if higher yields are to be obtained.

In addition to the use of maize for livestock feed, the findings from this study showed that the crop is also important for household consumption. Variety palatability (taste) was ranked highly by farmers during household surveys. The high ranking of taste agrees with findings of Louette and Smale (2000) as well as Tandzi et al. (2015) who identified taste as an important trait that is used to select maize varieties by resource-poor farmers in Mexico and Cameroon respectively. However, farmers were not given the opportunity to conduct organoleptic tests. It is possible that inclusion of organoleptic tests in the current study could have substantially changed the observed ranking of varieties. Farmers in Zanyokwe irrigation scheme of the EC, for example, preferred white-grained varieties over yellow because of their superior consumption quality and customer preference for green mealies (Fanadzo et al., 2010). 
Since some of the criteria that were important for farmers in these districts are not prioritised in formal plant breeding programmes, results of this study point to the repeatedly emphasised need to involve farmers in variety development and testing. Participatory farmer-breeder-chef collaborations have been suggested as an effective alternative for achieving productivity gains and adding the strength of culturally based plant breeding to the food movement (Bänziger \& Cooper, 2001; Brouwer, Murphy \& Jones, 2016). The improvement of rural livelihoods could be achieved if high yielding varieties, which possess desired traits, were selected and adopted by farmers (Odendo, De Groote \& Odongo, 2002; Ngonkeu et al., 2017; Rahman et al., 2015).

\section{CONCLUSION}

Farmers' variety selections and ranking differed across the two villages. Varieties selected in Jixini were Okavango, ZM 621, ZM 501, ZM 305 and ZM 423, while ZM 305, Nelson's choice, Okavango, ZM 501 and Afric 1 were selected in Mkhwezo. Yellow kernel colour considerably influenced selection of varieties by farmers, and resulted in high ranking of Okavango, despite the largest number of undesirable traits. The most preferred variety was not always statistically different from the highest yielding variety. The most important farmer selection criteria were also different across the two villages. Nonetheless, in order of their importance, farmers' preferred traits were taste, long cobs, big leaves, retainable seed, and big kernels. Differences in agro-ecological characteristics appeared to have had an important effect on differences on yield data, ranking of varieties by farmers and preferred selection criteria. This necessitates extensive evaluation for adaptability and acceptability before recommending varieties. The study demonstrated that numerous traits were used in variety selection, and there was no single variety that could meet all the requirements by farmers. Therefore, the understanding of the trade-offs that farmers are willing to make between various traits in different target sites is important. Given the preference for yellow kernel colour, it might be worthwhile to convert available stress-tolerant white varieties to yellow-grained types. Alternatively, variety Okavango, and possibly other locally grown yellow-grained landraces, could be improved for yield, stress tolerance, and other quality traits that will be desired and accepted by farmers.

\section{ACKNOWLEDGEMENT}

We are grateful for funding provided by the Technology Innovation Agency (TIA) and the Govan Mbeki Research and Development Centre (GMRDC) at the University of Fort Hare.

\section{REFERENCES}

ABEBE, G., ASSEFA, T., HARRUN, H. \& MESFINE, T., 2005. Participatory selection of drought tolerant maize varieties using mother and baby methodology: A case study in semi arid zones of the central rift valley of Ethiopia. African Crop Science Conference Proceedings, 7:1479-1485.

AGRICULTURAL GEO-REFERENCED INFORMATION SYSTEM (AGIS), 2011. Mapping and GIS software [viewed 15 October 2011]. Available from: http://www.agismap.com/agisinfo.html

ARAUS, J.L., SERRET, M.D. \& EDMEADES, G., 2012. Phenotyping maize for adaptation to drought. Front. Physiol., 3:305. 
BÄNZIGER, M. \& COOPER, M., 2001. Breeding for low input conditions and consequences for participatory plant breeding examples from tropical maize and wheat. Euphytica. 122(3):503-519.

BÄNZIGER, M., EDMEADES, G.O., BECK, D. \& BELLON, M., 2000. Breeding for drought and nitrogen stress tolerance in maize: From theory to practice. Mexico: CIMMYT.

BÄNZIGER, M., SETIMELA, P.S., HODSON, D. \& VIVEK, B., 2005. Breeding for improved abiotic stress tolerance in maize adapted to southern Africa. Agric. Water Manage., 80(1-3):212-224.

BOTHMA, J., 2004. Landscape and architectural devices for energy efficient South African suburban residential designs. M.Sc. Thesis submitted, University of Pretoria.

BROUWER, B.O., MURPHY, K.M. \& JONES, S.S., 2016. Plant breeding for local food system: A contextual review of end-use selection for small grains and dry beans in Western Washington. Renew. Agr. Food Sys., 31(2):172-178.

BUCHEYEKI, T.L., SHENNKALWA, E., KADADI, D. \& LOBULU, J., 2011. Assessment of rice production constraints and farmers preferences in Nzega and Igunga Districts. J. Adv. Dev. Res., 2(1):30-37.

CHIMONYO, V.G.P., 2012. An evaluation of stress tolerant open pollinated maize varieties in selected environments of the Eastern Cape Province, South Africa. M.Sc Thesis, University of Fort Hare.

CHIMONYO, V.G.P., MUTENGWA, C.S. \& CHIDUZA, C., 2014. Genotype x environment interactions and yield stability of stress-tolerant open-pollinated maize varieties in the Eastern Cape province, South Africa. S. Afr. J. Plant Soil, 31(2):61-68.

COURTOIS, B., BARTHOLOME, B., CHAUDHARY, D., MCLAREN, G., MISRA, C.H., MANDAL, N.P., PANDEY, S., PARIS, T., PIGGIN, C., PRASAD, K., ROY, A.T., SAHU, R.K., SAHU, V.N., SARKARUNG, S., SHARMA, S.K., SINGH, A., SINGH, H.N., SINGH, O.N., SINGH, N.K., SINGH, R.K., SINGH, R.K., SINGH, S., SINHA, P.K., SISODIA, B.V.S. \& TAKHUR, R., 2001. Comparing farmers and breeders rankings in varietal selection for low-input environments: A case study of rainfed rice in eastern India. Euphytica, 122(3):537-550.

DEPARTMENT OF AGRICULTURE FORESTRY AND FISHERIES (DAFF), 2012. Maize market value chain profile 2012 [viewed 15 November 2014]. Available from. https://www.nda.agric.za/docs/amcp/maize2012.pdf

DEPARTMENT OF AGRICULTURE FORESTRY AND FISHERIES (DAFF), 2015. South African varietal list as maintained by the registrar of plant improvement. seed crops [viewed 24 October 2017]. Available from: http://www.nda.agric.za

DE GROOTE, H., BETT, C., OKURO, J.O., ODENDO, M., MOSE, L. \& WEKESA, E., 2004. Direct estimation of maize crop losses due to stem borers in Kenya, preliminary results from 2000 and 2001. Proceedings of the 7th Eastern and Southern Africa Regional Maize Conference, 401-406. 
FANADZO, M., 2007. Weed management by small-scale irrigation farmers - the story of Zanyokwe. SA Irrigation, 29(6):20-24.

FANADZO, M., CHIDUZA, C., MNKENI, P.N.S., VAN DER STOEP, I., STEVEN, J., 2010. Crop production management practices as a cause for low water productivity at Zanyokwe Irrigation Scheme. Water SA, 36(1):27-36.

GADZIRIRAYI, C.T., MUTANDWA, E., CHIHIYA, Y.\& CHITSA, V., 2006. An assessment on the use of open pollinated varieties among small-holder farmers in Zimbabwe. Electronic Journal of environmental and Agricultural and Food Chemistry, 5(6):15901597.

GOMEZ, K.A. \& GOMEZ, A.A., 1984. Statistical procedures for agricultural research. United States of America: John Wiley and Sons.

HEBINCK, P., FAY, D. \& KONDLO, K., 2011. Land and agrarian reform in South Africa's Eastern Cape province: Caught by continuities. J. Agrar. Change, 11(2):220-240.

JACOBSON, K. \& MYHR, A.I., 2013. GM crops and smallholders: Biosafety and local practice. J. Environ. Dev., 22(1):104 -124.

JOSHI, A. \& WITCOMBE, J.R., 1996. Farmer participatory crop improvement. II. Participatory varietal selection, a case study in India. Exp. Agr., 32(4):461-477.

LOUETTE, D. \& SMALE, M., 2000. Farmers' seed selection practices and traditional maize cultivars in Cuzalapa, Mexico. Euphytica, 113(1):25-41

MAGOROKOSHO, C., VIVEK, B. \& MACROBERT, J., 2008. Characterization of maize germplasm grown in eastern and southern Africa: Results of the 2007 regional trials coordinated by CIMMYT.

MAPIYE, C., CHIMONYO, M., DZAMA, K., RAATS, J.G. \& MAPEKULA, M., 2009. Opportunities for improving Nguni cattle production in the smallholder farming systems of South Africa. Livest. Sci., 124(1-3):196-204.

MASIFUNDE EDUCATION AND DEVELOPMENT TRUST PROGRAM (MEDTP), 2010. Threats to the food security and sovereignty in the Eastern Cape. Impacts of the Massive Food Production Programme (MFPP), GMOs and cash crops in four villages in the Amatole District Municipality [viewed 31 May 2013]. Available from: http://www.biosafety-info.net/file_dir/9260820094dda3a605ad33.pdf

MATIWANA, Z., 2011. The ugly truth about GM crops in the Eastern Cape [viewed 1 July 2011]. Available from: 01/07/2011, http://www.ru.ac.za/modules/blog_include/blog_content.php?=1973.

MCCAIN, M., 2005. Annexure 2: District Profile Eastern Cape Tambo District Municipality (DC15). Programme of Support to Local Economic Development in the Eastern Cape. Eastern Cape Competitive Advantage Assessment And Training Support Project. European Consultants Organisation (ECO) [viewed 6 August 2011]. Available from: http://www.thinasinako.co.za/files/documents/290806175904.pdf. 
MITI, F., 2007. Breeding investigations of maize (Zea mays L.) genotypes for tolerance to low nitrogen and drought in Zambia. PhD Thesis, University of KwaZulu-Natal.

MONDE, N., 2003. Household food security in rural areas of central Eastern Cape: The case of Guquka in Victoria East and Koloni in Middledrift districts. PhD Thesis, University of Fort Hare.

MPHALALA, D., 2007. Community based seed production: Limpopo farmer's strategies of resisting drought [viewed 1 October 2014]. Available from: http://unpan1.un.org/intradoc/groups/public/documents/CPSI/UNPAN026456.pdf

MUSEMWA, L., MUSHUNJE, A., CHIMONYO, M., FRASER, G., MAPIYE, C, \& MUCHENJE, V., 2008. Nguni cattle marketing constraints and opportunities in the communal areas of South Africa. Afr. J. Agric. Res., 3(4):239-245.

NGONKEU, E.L.M., TANDZI, L.N., DICKMI, C.V., NARTEY, E., YEBOAH, M., NGEVE, J., MAFOUASSON, H.A., KOSGEI, A., WOIN, N. \& GRACEN, V., 2017. Identification of farmer's constraints to maize production in the humid forest zone of Cameroon. Journal of Experimental Agriculture International, 15(3):1-9.

NKONGOLO, K.K., CHINTHU, K.K.L., MALUSI, M. \& VOKHIWA, Z., 2008. Participatory variety selection and characterization of Sorghum (Sorghum bicolor (L.) Moench) elite accessions from Malawian gene pool using farmer and breeder knowledge. Afr. $J$. Agric. Res., 3(4):273-283.

NUSS, E.T. \& TANUMIHARDJO, S.A., 2011. Quality protein maize for Africa: Closing the protein inadequacy gap in vulnerable populations. Adv. Nutri., 2(3):217-224.

ODENDO, M., DE GROOTE, H. \& ODONGO, O.M., 2002. Assessment of farmers' preferences and constraints to maize production in the moist mid-altitude zone of eestern Kenya. In 5th International Conference of the African Crop Science Society, Lagos, Nigeria (Vol. 2126 p. 2001).

RAHMAN, M.A., THANT, A.A., WIN, M., TUN, M.S., MOET, M.P., THU, A.M., WIN, K.T., MYINT, O., MYINT, T., TUNTUN, Y., LABIOS, R.V., CASIMERO, M.C., GREGORIO, G.B., JOHNSON, D.E., SINGLETON, G.R. \& SINGH, R.K., 2015 Participatory varietal selection (PVS). A "bottom-up" breeding approach helps rice farmers in the Ayeyarwady Delta, Myanmar. SABRAO J. Breed. Genet., 47(3):299-314.

SETIMELA, P.S., VIVEK, A.B., BANZIGER, M., CROSSA, J. \& MAIDENI, F., 2007. Evaluation of early to medium maturing open pollinated maize varieties in SADC region using GGE biplot based on the SREG model. Field Crops Res., 103(3):161-169.

SIBANDA, M., MUSHUNJE, A. \& MUTENGWA, C.S., 2016. An evaluation on the profitability of growing improved maize open pollinated varieties in the Eastern Cape province, South Africa. J. Dev. Agric. Econ., 8(1):1-13.

SILWANA, T.T., 2000. Performance of maize/bean and maize/pumpkin intercrops under different planting combinations and weeding in Transkei, South Africa. M.Sc Thesis, University of Fort Hare. 
S. Afr. J. Agric. Ext.

Vol. 47 No. 1, 2019: 103 - 117

http://dx.doi.org/10.17159/2413-3221/2019/v47n1a493
Chimonyo, Mutengwa,

Chiduza \& Tandzi

(License: CC BY 4.0)

SINGH, Y.P., NAYAK, A.K., SHARMA, D.K., GAUTAM, R.K., SINGH, R.K., SINGH, R., MISHRA, V.K., PARIS, T. \& ISMAIL, A.M., 2013. Farmers' participatory varietal selection: A sustainable crop improvement approach for the 21 st century. Agroecol. Sust. Food, 38(4):427-444.

STATS SA, 2016. Community survey 2016: Agricultural households [viewed 12 November 2017]. Available from: http://www.statssa.gov.za/publications/03-01-05/03-01052016.pdf.

TADESSE, D., MEDHIN, Z.G. \& AYALEW, A., 2014. Participatory on farm evaluation of improved maize varieties in Chilga district of North Western Ethiopia. J. Agric. For., 4(5):402-407.

TANDZI, N.L., NGONKEU, E.M., NARTEY, E., YEBOAH, M., NGEVE, J., MAFOUASSON, H.A., NSO-NGANG, A., BASSI, O. \& GRACEN, V., 2015. Farmers' adoption of improved maize varieties in the humid forest area of Cameroon. Int. J. Sci. Eng. Appl. Sci., 1:17-28.

TREGURTHA, N., 2009. Review of the Eastern Cape's Siyakhula/Massive maize project [viewed 4 September 2018]. Available from: http://www.tips.org.za/files/u65/review_of_siyakhula__norma_tregurtha.pdf

VAN AVERBEKE, W. \& BENNETT, J., 2007. Agro-ecology, land use and smallholder farming in the Central Eastern Cape. In Livelihoods and landscapes, (pp. 67-90). Brill.

WATER SERVICE REPORT TOOL. 2001. [viewed 12 September 2011]. Available from: http://www.dwaf.gov.za/dir_ws/WaterServices/reports/pg_reports.asp? 